\title{
Waarderingswoord aan J.L. Helberg
}

\author{
F.N. Lion-Cachet \\ Dekaan: Fakulteit Teologie \\ Potchefstroomse Universiteit vir $\mathrm{CHO}$ \\ POTCHEFSTROOM
}

Ter inleiding wil ek onomwonde sê dat dit vir my 'n besondere eer is om hiermee 'n kort waarderingswoord uit te spreek teenoor 'n hooggeagte kollege en lewenslange vriend - Jaap Helberg. Hy het aan die einde van 1993 as voltydse professor aan die Teologiese Skool Potchefstroom geëmeriteer waar hy 23 jaar gearbei het Dit het die lang die doseringstydperk van 32 jaar afgesluit, want hy het met sy benoeming aan die Teologiese Skool Potchefstroom reeds nege jaar as professor aan die Hammanskraalse Teologiese Skool gedien.

Jacob Lewis Helberg is op die 4de Desember 1928 in Rooiberg, distrik Waterberg gebore. Hy het in 1945 as skolier van die Hoërskool Nylstroom gematrikuleer. Hy het sy beroepsarbeid as klerk by Yskor begin terwyl hy terselfdertyd met sy studie voortgaan het en het in 1948 sy B.A.-graad aan die Universiteit van Pretoria behaal. Hy het sy studies aan die $\mathrm{PU}$ vir $\mathrm{CHO}$ voortgesit en het agtereenvolgens sy B.A. Hons. (1951), M.A. (1952), Th.B. (1953), Th.M. (1961) en sy Th.D. (1966) behaal.

Jaap het sy vrugbare predikantsdiens in 1954 te Rustenburg-Elandskraal begin, en het sy werk later in Krugersdorp voortgesit (1958-1961). Vanaf 1961 staan hy in die diens van die opleiding van predikante as dosent en professor te Hammanskraal (tot in 1970) en Potchefstroom (1971-1993). Hy is getroud met Regina Barbara Snyman (Kokkie) en uit die huwelik is twee seuns en twee dogters gebore.

As akademikus het hy uitmuntende werk gelewer. Hy is met pragtige gawes toegerus en was begerig om navorsing te doen en te skrywe. Talryke publikasies het dan ook uit sy pen verskyn. Onder hulle is nege handboeke vir die skool en universiteit waarvan die volgende die belangrikste is: Openbarıngsgeskiedenis van die Ou Testament I en II (1976), Die Here regeer: Openbaringslyn deur die Ou Testament (19883); V'erklaring en predikıng van die Ou Testament (1983); Klaagliedere. Ontnuglering en hoop (1984) en Die verbondsvolk se verhouding tot sy land (1990). Sy 32 wetenskaplike artikels het in verskeie geakkrediteerde tydskrifte verskyn. Sy lewcnsbeskoulike populêr-wetenskaplike boeke en brosjures tel 'n verdere 20. Hierby moet ook nog sy ander publikasies in Woord en l Saad, Die Kerkblad en ander tydskrifte gevoeg word - bydraes wat self die 
reuse getal van 163 tel. Die waarde van al hierdie bydraes mag nie onderskat word nie.

Helberg se teologie het 'n vaste beginpunt: die Bybel is die gesagvolle woord van God omdat "die Bybel dit vir homself opeis en omdat hierdie aanspraak met ons verstand gekontroleer kan word, of beter gestel, omdat dit deur ons verstand toegestem kan word" (Helberg, 1983:8)' . In sy teologiese benadering het hy nooit geswig voor die verleidelike absolute literêr- of histories-kritiese metodes nie. Die waardes van hierdie menssydige sienings is nie ontken nie, maar hy het in sy teologie die openbaringhistoriese gegewens as die belangrikste aspek van sy wetenskaplike nadenke beskou. In sy verklaring het die literêre ondersoek (literatuursoorte, stylsoorte, woordbetekenisse, samestelling) en die historiese ondersoek - die Bybel is ' $n$ historiese werklikheid - aandag gekry, maar hy het veral sy verklaring in die lig van een groot openbaringslyn verdiskonteer. Hy het die problematiek met betrekking tot ' $n$ sentrale openbaringslyn erken maar het geoordeel dat die Ou Testament tog net een sentrale openbaringslyn aangebied het: "God se werksaamheid in en deur die geskiedenis wat Hy met sy openbaring begelei en deurvoer" (Helberg, 1983:60). Hy het geoordeel dat die openbaringsgeskiedenis van God se lewewekkende koninkryksheerskappy getuig: "Verlossing vind alleen plaas deur God se wonderdadige optrede, sy lewewekkende heerskappy. God laat sy heerskappy deurgaan, selfs deur ondergang en die dood heen" (Helberg, 1983:63). Vir hom is hierdie genadige optrede van die Here paradoksaal. Die openbaringslyn kan van die skepping tot by die herskepping nagevors word. In sy latere studies het hy op die plek van die verbondsvolk se verhouding tot die land gekonsentreer. Sy navorsing kan getipeer word as koninkryksnavorsing. Jaap Helberg sal altyd bekend wees as die teoloog wat die koninkryksheerskappy van God in die Ou Testament met oorgawe nagevors en verwoord het.

Hy het lewendig deelgeneem aan die universitêre lewe, met vuur klas gegee, belangstelling vir nagraadse studie gewek, aan drie doktorsgraadstudente leiding gegee en het met bekwaamheid as Dekaan en as Rektor van die Teologiese Skool Potchefstroom opgetree. Hy het voordragte by verskeie buitelandse universiteite en kolleges gelewer, as gasdosent by Christelıke universiteite in Tokyo en Kosin opgetree, en het ook sy bydraes by binnelandse sowel as die buitelandse konferensies gelewer. Voorwaar pragtige prestasies!

Jaap Helberg het ' $n$ besondere bydrae as Bybelvertaler gelewer (1985-1990). Dié kostelike vertaling is deur die Afrikaanse kerkegemeenskappe en volk hoog waardeer en hy het as erkenning vir sy aandeel pennings en oorkondes van die

1 HELBERG, J.L. 1983. Verklaring en predikıng van dic Ou Testament Potchefstroom PTP 
Nederduitsch Hervormde Kerk van Afrika, die FAK en die SA Akademie vir Wetenskap en Kuns ontvang.

In die bediening van die Woord het sy prediking diep ingeslaan. Hy het ook 'n reuse bydrae gelewer in die kerklike lewe deur sy wyse adviese aan die meerdere vergaderings. As deputaat het hy die Gereformeerde Ekumeniese Sinodes bygewoon en samesprekings met die Christian Reformed Church of North America gevoer. Hy was ook deputaat op verskeie van die deputaatskappe van die Gereformeerde Sinode van die Gereformeerde Kerke in Suid-Afrika, veral in die groepe wat die volkereverhoudings, ekumeniese sake en Bybelvertalings moes hanteer.

Ons het in Jaap Helberg 'n baie mooi gawe van die Here ontvang. Sy rustige en wyse insig, sy standvastige en oortuigende optrede en daarby sy gemaklike en vriendehke menseverhouding waardeur hy ander nie weggestoot het nie maar hulle eerder nader getrek en bemoedig het, het van hom 'n sentrale en beminde figuur in God se koninkryk gemaak. Dit was en is 'n voorreg om al die jare saam met hom te werk en deur sy woorde en optrede geinspireer te word.

Ons is almal dankbaar dat hy en sy gade wat hom al die jare bygestaan het, nog betreklik goeie gesondheid geniet en gewillig is om nog hulle deel te doen wat aan hulle toegewys mag word. Mag die Here hulle nog baie jare vir sy kerk, die volk en vir ons almal spaar en bewaar. 
